\title{
MODIFIKASI TEPUNG SORGUM DENGAN METODE FERMENTASI MENGGUNAKAN BAKTERI ASAM LAKTAT Lactobacillus bulgaricus
}

\author{
Kristinah Haryani*, Pradhipta Rizka Lakzita, Putri Puspita Sari \\ Departemen Teknik Kimia, Fakultas Teknik, Universitas Diponegoro, \\ Jl. Prof. Soedarto, SH, Kampus Undip Tembalang, Semarang, Indonesia 50275 \\ *Email : krisyanidelapantiga@gmail.com
}

\begin{abstract}
Abstrak
Sorghum merupakan sumber karbohidrat yang cukup potensial di Indonesia, namun mempunyai beberapa kekurangan diantaranya daya cerna karbohidrat dan proteinnya kurang bagus dibandingkan tepung yang lain. Pada penelitian ini sorghum dimodifikasi dengan metode fermentasi menggunakan bakteri asam laktat Lactobacillus bulgaricus untuk meningkatkan daya cerna protein dan daya cerna karbohidratnya. Proses penelitiannya dilakukan melalui 3 tahap, yaitu (1)pembuatan tepung sorghum (2) pembuatan tepung sorghum fermentasi, (3) tahap analisa produk. Variabel kendali dalam penelitian ini meliputi : suhu operasi dan kecepatan pengadukan. Variabel bebasnya berupa waktu operasi fermentasi $(24 ; 48$ jam) dan konsentrasi starter $(4 ; 6 \% \mathrm{v} / \mathrm{v})$. Dari penelitian yang telah dilakukan diperoleh hasil bahwa kadar air pada tepung sorghum termodifikasi mengalami peningkatan setelah proses fermentasi karena terjadi proses metabolisme bakteri. Untuk kadar protein pada tepung sorghum termodifikasi mengalami peningkatan setelah proses fermentasi karena adanya hidrolisis protein oleh enzim proteinase. Namun, kadar karbohidrat tepung sorghum termodifikasi setelah proses fermentasi mengalami penurunan karena adanya degradasi karbohidrat. Daya cerna protein dan daya cerna karbohidrat antara tepung sorghum sebelum fermentasi (native) dan sesudah fermentasi mengalami peningkatan karena adanya proses proteolisis.
\end{abstract}

Kata kunci: fermentasi,modifikasi , Lactobacillus bulgaricus, tepung sorghum

\section{PENDAHULUAN}

Tanaman sorgum memiliki beberapa kelebihan yaitu umur tanam yang pendek, dapat ditanam pada lahan kering, lebih tahan terhadap hama dan penyakit serta biaya produksi yang rendah (Biba, 2016). Selain itu, tepung sorgum juga memiliki keunggulan antara lain tidak mengandung gluten dan memiliki glikemik index yang rendah, sehingga baik bagi penderita alergi gluten dan diabetes .

Kandungan nutrien dalam sorgum bervariasi tergantung pada varietas, tetapi umumnya mengandung protein kasar 8,9 $10,48 \%$, lemak $2,5-3,7 \%$, serat kasar $1,2-$ $3,01 \%$, abu $1,2-6,94 \%$, pati dan gula $61,24-$ $76,6 \%$ dengan berat kering (BK) sekitar 88,94 - 93,31\%. Komposisi asam amino sorgum cukup lengkap baik asam amino esensial maupun non esensial dan juga mengandung vitamin penting seperti vitamin $\mathrm{A}$, vitamin $\mathrm{K}$, vitamin B6, vitamin B12 dan choline (Etuk dkk., 2012). Namun, dalam pemanfaatan sorgum juga memiliki beberapa kendala yaitu rendahnya daya cerna karbohidrat dan protein, serta keberadaan senyawa tanin yang dapat menyebabkan bau langu dan rasa sepat sehingga tidak enak untuk dikonsumsi. Protein dalam sorgum sulit dicerna karena protein tersebut tersimpan dalam protein bodies yang akan tetap utuh selama pemasakan (Setiarto dkk, 2016).

Fermentasi adalah metode yang telah lama digunakan dalam proses pengolahan bahan pangan dengan tujuan untuk meningkatkan daya simpan, memperbaiki palatabilitas (daya penerimaan) dan memperbaiki daya cerna serta meningkatkan nilai nutrisi (Fadlallah dkk., 2010). Fermentasi sorgum secara tradisional diketahui secara nyata dapat memperbaiki sifat fungsional tepung sorgum (Elkhalifa dkk., 2005). Proses fermentasi tepung sorgum secara signifikan mampu meningkatkan daya cerna protein dan pati (Alka dkk., 2012). Dalam penelitian ini fermentasi dilakukan dengan memanfaatkan bakteri asam laktat Lactobacillus bulgaricus, dimana bakteri asam laktat ini dapat mengurangi senyawa antinutrien seperti tannin, fitat dan alfatoksin. (Coreia et al, 2010). 


\section{Bahan dan metode \\ 2.1 Bahan}

Bahan utama dalam penelitian ini adalah biji sorgum yang dibeli dari Pasar Burung Karimata, Semarang, Jawa Tengah. Enzim yang digunakan pada proses analisa yaitu enzim pepsin. Bahan penunjang lainnya adalah aquadest, glukosa standart, $\mathrm{HCl}, \mathrm{NaOH}$, Fehling A, Fehling B, larutan Luff Schrool serta bahan-bahan pendukung lainnya untuk preparasi dan analisa hasil.

\subsection{Metode penelitian}

Prosedur penelitian meliputi tiga tahap yaitu (1) Fermentasi biji sorgum, (2) Pembuatan tepung sorgum termodifikasi, (3) Analisa hasil. Penjelasan lebih lanjut adalah sebagai berikut :

(1) Fermentasi Biji Sorgum

Proses fermentasi biji sorgum dilakukan melalui tahap semi padat menggunakan inokulum $L$. bulgaricus. Proses fermentasi biji sorgum dilakukan dengan beberapa tahapan meliputi penimbangan biji sorgum, pencucian, perendaman, pemasakan/perebusan, penirisan, fermentasi semi padat, pengeringan dan penepungan. Pencucian biji sorgum dilakukan untuk menghilangkan kotoran yang menempel pada biji. Selanjutnya biji sorgum direndam dengan aquades steril sampai seluruh biji terendam sekitar $5 \mathrm{~cm}$ dari batas permukaan air selama 4-6 jam. Biji yang telah ditiriskan kemudian direbus selama 30 menit. Selanjutnya biji ditiriskan dan didinginkan sampai mencapai suhu sekitar $40^{\circ} \mathrm{C}$ (Setiarto dkk., 2016). Biji sorgum yang telah dipreparasi dimasukkan dalam erlenmeyer steril. Setelah itu proses fermentasi semi padat dilakukan pada suhu ruang $\left( \pm 30^{\circ} \mathrm{C}\right)$ selama 24 dan 48 jam. Pada proses fermentasi semi padat, tepung sorgum yang telah dipreparasi sebelumnya sebanyak 50\% (w/v) dan aquades sebanyak $50 \%(\mathrm{w} / \mathrm{v})$. Campuran tepung sorgum dan aquades yang berupa slurry kemudian di sterilisasi menggunakan autoclave pada suhu $121^{\circ} \mathrm{C}, 2 \mathrm{~atm}$ selama 15 menit. Kemudian diinokulasikan dengan 4 dan $6 \%$ (v/v) inokulum L.bulgaricus selama 24 dan 48 jam pada suhu $30^{\circ} \mathrm{C}$.

(2) Pembuatan Tepung sorgum Termodifikasi

Setelah proses fermentasi semi padat, selanjutnya tepung sorgum ditiriskan, dikeringkan dengan oven pada suhu $60{ }^{\circ} \mathrm{C}$ selama 16 jam. Setelah itu, tepung sorgum diayak dengan ukuran 80 mesh. (Kurniadi dkk., 2013).

(3) Analisa hasil meliputi analisa kadar air (Metode Thermogravimetri), kadar protein (Metode Kjeldahl), kadar karbohidrat (Metode Fehling), daya cerna protein (Metode Mertz), daya cerna karbohidrat (Metode Asam)

\section{Hasil dan Pembahasan}

\subsection{Kadar Air pada Tepung Sorgum Termodifikasi}

Kadar air tepung sorgum terfermentasi pada penelitian ini dapat dilihat pada Gambar 1 .

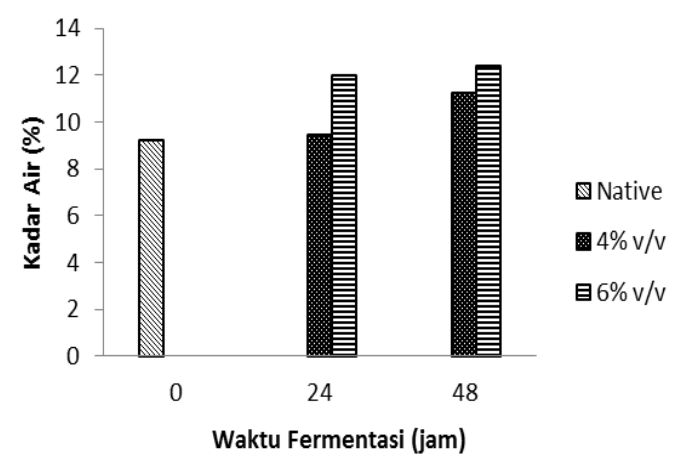

Gambar 1. Kadar air tepung sorghum termodifikasi menggunakan starter $L$. bulgaricus dengan variasi kensentrasi starter dan lama fermentasi

Dari Gambar 1. menunjukkan bahwa kadar air antara tepung sorgum sebelum fermentasi (native) dan sesudah fermentasi mengalami peningkatan. Pada penelitian ini menggunakan konsentrasi starter L. bulgaricus sebesar $4 \% \mathrm{v} / \mathrm{v}$ dan $6 \% \mathrm{v} / \mathrm{v}$. Didapatkan hasil kadar air pada tepung sorgum sebelum fermentasi (native) sebesar $9,20 \%$ dan sesudah fermentasi menggunakan starter $4 \% \mathrm{v} / \mathrm{v}(24 \mathrm{jam}), 4 \% \mathrm{v} / \mathrm{v}$ (48 jam), 6\% v/v (24 jam) dan 6\% v/v (48 jam) berturut-turut adalah $9,48 \% ; 11,23 \% ; 12,00 \%$ dan $12,40 \%$. Dari hasil penelitian, dapat dilihat bahwa pengaruh fermentasi dapat meningkatkan kadar air. Selain itu, semakin lama waktu fermentasi dan semakin tinggi konsentrasi starter maka semakin tinggi kadar air dalam tepung sorgum terfermentasi. Kadar air tepung sorghum terfermentasi pada penelitian ini memenuhi standar tepung komersial dalam pada umumnya seperti syarat mutu tepung sorghum dengan kadar air maksimal 14\% (b/b) dalam SNI 01-3157 (Badan Standardisasi Nasional, 1992). 
Menurut Fathurrohman (2012), selama fermentasi terjadi proses metabolisme dan perombakan senyawa makromolekul menjadi senyawa yang lebih sederhana. Menurut Murtini (2016) lama fermentasi merupakan salah satu faktor terpenting penyebab meningkatnya kadar air sehingga dengan meningkatkan waktu fermentasi kadar air akan meingkat pula. Peningkatan kadar air ini akibat penambahan air dari hasil metabolisme mikrobia selama fermentasi. Menurut Rochmah (2008) air merupakan salah satu produk hasil fermentasi aerob. Selama fermentasi, mikrobia mencerna substrat dan menghasilkan air, karbon dioksida dan sejumlah energi.

\subsection{Kadar Protein pada Tepung Sorgum Termodifikasi}

Dalam penelitian ini, dilakukan analisa kadar protein selama fermentasi tepung sorgum, dan berikut dapat dilihat dalam Gambar 2 :

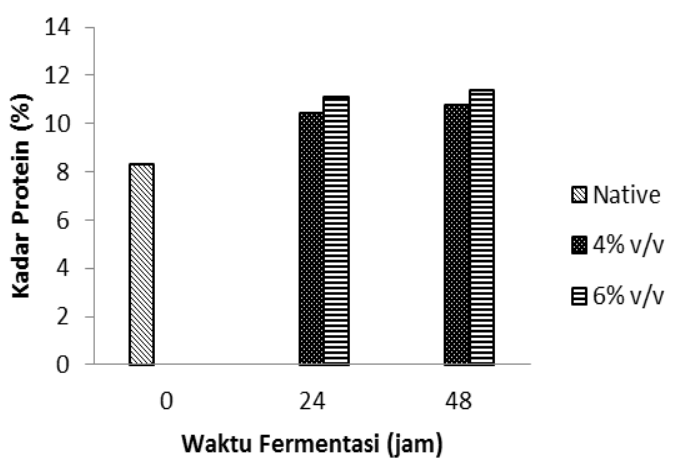

Gambar 2. Kadar protein tepung sorghum termodifikasi menggunakan starter $L$. bulgaricus dengan variasi kensentrasi starter dan lama fermentasi

Dari Gambar 2. menunjukkan bahwa kadar protein antara tepung sorgum sebelum fermentasi (native) dan sesudah fermentasi mengalami peningkatan. Pada penelitian ini menggunakan konsentrasi starter L. bulgaricus sebesar $4 \%$ v/v dan $6 \%$ v/v. Didapatkan hasil kadar protein pada tepung sorgum sebelum fermentasi (native) sebesar 8,29\% dan sesudah fermentasi menggunakan starter $4 \%$ v/v (24 jam), $4 \%$ v/v (48 jam), $6 \%$ v/v (24 jam) dan $6 \%$ $\mathrm{v} / \mathrm{v}$ (48 jam) berturut-turut adalah 10,43\%; $10,75 \% ; 11,08 \%$ dan $11,40 \%$. Dari hasil penelitian, dapat dilihat bahwa pengaruh fermentasi dapat meningkatkan kadar protein. Selain itu, semakin lama waktu fermentasi dan semakin tinggi konsentrasi starter maka semakin tinggi kadar protein dalam tepung sorgum terfermentasi.
Menurut Faris Fathurrohman (2012), semakin tinggi konsentrasi starter dan lama fermentasi berakibat pada meningkatnya kadar protein pada tepung sorghum terfermentasi. Menurut Rahman (1992) enzim proteinase akan menghidrolisis protein menjadi peptida yang sederhana. Adanya kenaikan kadar protein terlarut diperoleh dari aktivitas enzim proteinase yang dihasilkan oleh mikrobia yang ada dalam proses fermentasi. Besarnya konsentrasi starter membuat populasi Lactobacillus bulgaricus semakin meningkat, sehingga dominasi bakteri tersebut membuat kadar protein terlarut meningkat.

\subsection{Kadar Karbohidrat pada Tepung} Sorgum Termodifikasi

Dalam penelitian ini, dilakukan analisa kadar karbohidrat selama fermentasi tepung sorgum, dan berikut dapat dilihat dalam Gambar 3 :

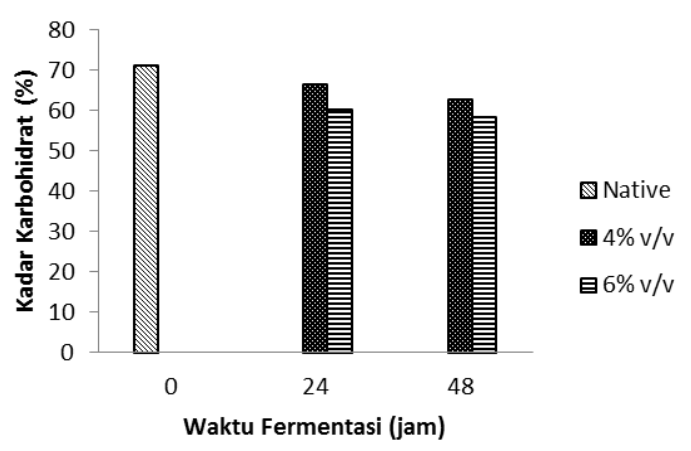

Gambar 3. Kadar karbohidrat tepung sorghum termodifikasi menggunakan starter

L. bulgaricus dengan variasi kensentrasi starter dan lama fermentasi

Dari Gambar 1. menunjukkan bahwa kadar karbohidrat antara tepung sorgum sebelum fermentasi (native) dan sesudah fermentasi mengalami penurunan. Pada penelitian ini menggunakan konsentrasi starter L. bulgaricus sebesar $4 \%$ v/v dan 6\% v/v. Didapatkan hasil kadar karbohidrat pada tepung sorgum sebelum fermentasi (native) sebesar 70,09\% dan sesudah fermentasi menggunakan starter $4 \%$ v/v (24 jam), $4 \%$ v/v (48 jam), 6\% v/v (24 jam) dan 6\% v/v (48 jam) berturut-turut adalah 66,31\%; $62,67 \%$; 60,08\% dan 58,06\%. Dari hasil penelitian, dapat dilihat bahwa pengaruh fermentasi dapat menurunkan kadar karbohidrat. Selain itu, semakin lama waktu fermentasi dan semakin tinggi konsentrasi starter maka semakin rendah kadar karbohidrat dalam tepung sorgum terfermentasi. 
Penurunan kadar karbohidrat selama fermentasi menunjukkan bahwa adanya proses degradasi karbohidrat. Yudi Pranoto dkk. (2012), menyatakan bahwa matriks protein yang terkandung dalam butiran karbohidrat dalam tepung sorgum terdegradasi selama fermentasi. Bakteri proteolitik dalam medium fermentasi digunakan untuk menghidrolisis matriks protein yang menyebabkan pelepasan butiran karbohidrat dari matriks protein. Sehingga karbohidrat dapat lebih mudah berikatan dengan bakteri amilase dan lebih mudah untuk dihidrolisa menjadi molekul yang lebih sederhana, seperti dekstrin, disakarida, dan monosakarida (Xu et al., 2020).

\subsection{Daya Cerna Protein pada Tepung Sorgum Termodifikasi}

Dalam penelitian ini, dilakukan analisa daya cerna protein selama fermentasi tepung sorgum, dan berikut dapat dilihat dalam Gambar 4 :

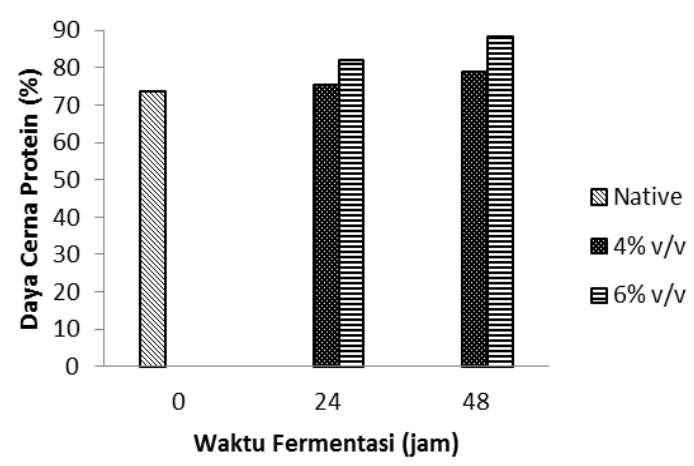

Gambar 4. Daya cerna protein tepung sorghum termodifikasi menggunakan starter L. bulgaricus dengan variasi kensentrasi starter dan lama fermentasi

Dari Gambar 4. menunjukkan bahwa daya cerna protein antara tepung sorgum sebelum fermentasi (native) dan sesudah fermentasi mengalami peningkatan. Pada penelitian ini menggunakan konsentrasi starter L. bulgaricus sebesar $4 \%$ v/v dan 6\% v/v. Didapatkan hasil daya cerna protein pada tepung sorgum sebelum fermentasi (native) sebesar 73,47\% dan sesudah fermentasi menggunakan starter $4 \%$ v/v (24 jam), $4 \%$ v/v (48 jam), 6\% v/v (24 jam) dan $6 \% \mathrm{v} / \mathrm{v}(48 \mathrm{jam})$ berturut-turut adalah $75,30 \% ; 78,75 \% ; 82,08 \%$ dan $88,17 \%$. Dari hasil penelitian, dapat dilihat bahwa pengaruh fermentasi dapat meningkatkan daya cerna protein. Selain itu, semakin lama waktu fermentasi dan semakin tinggi konsentrasi starter maka semakin tinggi daya cerna protein dalam tepung sorgum terfermentasi.

Peningkatan daya cerna protein tepung sorgum yang difermentasi dikaitkan dengan hidrolisis protein dan tannin dalam sorgum. Pranoto dkk. (2012), menyatakan bahwa $L$. bulgaricus mengalami aktivitas proteolitik. Selama fermentasi, proses proteolysis protein menghasilkan peptida dan asam amino, sehingga daya cerna protein meningkat. Selain itu, L. bulgaricus mengalami aktivitas tannase yang dapat memisahkan tannin kompleks dengan protein. Maka hidrolisis matriks protein terjadi dan ikatan peptide dipecah menjadi ikatan yang lebih kecil. Hal ini membuat protein lebih mudah untuk dicerna oleh pepsin, sehingga daya cerna protein mengalami peningkatan.

\subsection{Daya Cerna Karbohirat pada Tepung Sorgum Termodifikasi}

Dalam penelitian ini, dilakukan analisa daya cerna karbohidrat selama fermentasi tepung sorgum, dan berikut dapat dilihat dalam Gambar 5:

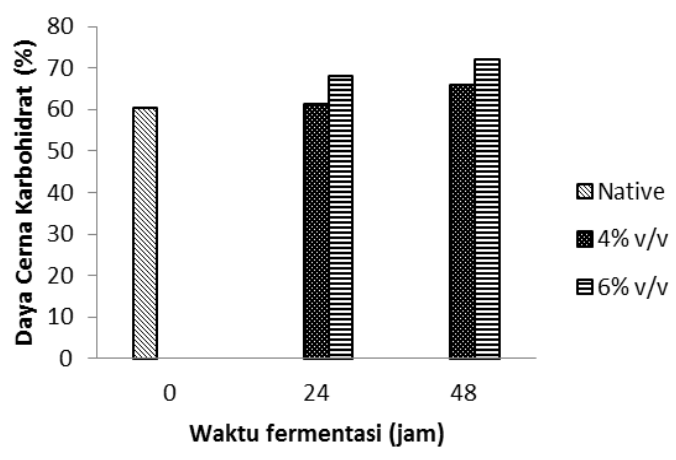

Gambar 5. Daya cerna karbohidrat tepung sorghum termodifikasi menggunakan starter

L. bulgaricus dengan variasi kensentrasi starter dan lama fermentasi

Dari Gambar 5. menunjukkan bahwa daya cerna karbohidrat antara tepung sorgum sebelum fermentasi (native) dan sesudah fermentasi mengalami peningkatan. Pada penelitian ini menggunakan konsentrasi starter L. bulgaricus sebesar $4 \% \mathrm{v} / \mathrm{v}$ dan $6 \% \mathrm{v} / \mathrm{v}$. Didapatkan hasil daya cerna karbohidrat pada tepung sorgum sebelum fermentasi (native) sebesar $60,27 \%$ dan sesudah fermentasi menggunakan starter $4 \% \mathrm{v} / \mathrm{v}$ (24 jam), $4 \% \mathrm{v} / \mathrm{v}$ (48 jam), 6\% v/v (24 jam) dan 6\% v/v (48 jam) berturut-turut adalah $61,29 \% ; 66,03 \% ; 67,98 \%$ dan $72,08 \%$. Dari hasil penelitian, dapat dilihat bahwa pengaruh fermentasi dapat 
meningkatkan daya cerna karbohidrat. Selain itu, semakin lama waktu fermentasi dan semakin tinggi konsentrasi starter maka semakin tinggi daya cerna karbohidrat dalam tepung sorgum terfermentasi.

Menurut Pranoto dkk. (2013), protein sorgum dan granula pati berada di dalam matriks protein. Fermentasi menyebabkan proses protelisis sehingga matriks protein mengelilingi granula pati. Maka granula pati dilepaskan dari matriks protein dan mudah dihidrolisis oleh amylase, sehingga meningkatkan daya cerna karbohidrat. Fermentasi juga dapat memecahkan granula pati yang besar menjadi granula pati yang lebih kecil. Granula pati yang lebih kecil lebih rentan terhadap hidrolisis enzimatik karena luas permukaan spesifik yang lebih banyak terkena enzim yang menyebabkan peningkatan daya cerna karbohidrat (Singh et al., 2010).

\section{KESIMPULAN DAN SARAN}

Dari penelitian yang telah dilakukan diperoleh hasil bahwa kadar air pada tepung sorghum termodifikasi mengalami peningkatan setelah proses fermentasi karena terjadi proses metabolisme bakteri. Untuk kadar protein pada tepung sorghum termodifikasi mengalami peningkatan setelah proses fermentasi karena adanya hidrolisis protein oleh enzim proteinase. Namun, kadar karbohidrat tepung sorghum termodifikasi setelah proses fermentasi mengalami penurunan karena adanya degradasi karbohidrat. Daya cerna protein dan daya cerna karbohidrat antara tepung sorghum sebelum fermentasi (native) dan sesudah fermentasi mengalami peningkatan karena adanya proses proteolisis.

\section{UCAPAN TERIMA KASIH}

Terima kasih disampaikan kepada temanteman, laboran, dan pihak-pihak yang telah banyak membantu atas terselesaikannya jurnal penelitian ini.

\section{DAFTAR PUSTAKA}

Alka, S., Neelam, Y. dan Shruti, S. (2012). Effect of fermentation on physicochemical properties and in vitro starch and protein digestibility of selected cereals. International Journal of Agricultural and Food Science. 2(3): $66-$ 70.

Biba, M.A., 2016, Prospek Pengembangan Sorghum untuk Ketahanan Pangan dan
Energi, Iptek Tanaman Pangan, Vol 6, no $2,21-13$

Correia I., Nunes A., GuedesA., Barros A.S., DelgadilloI., 2010, Screening of lactic acid bacteria potentially useful for sorghum fermentation, Journal of Cereal Science 52 (2010) 9-15

Elkhalifa, A.E.O., Schiffler, B. dan Bernhardt, R. (2005). Effect of fermentation of the functional properties of sorgum flour. Food Chemistry 92:1- 5.

Etuk, E. B., Ifeduba, A.V., Okata, U.E., Chiaka, I., Okoli, Ifea-nyi, C., Okeudo, N.J., Esonu, B.O., Udedibie, A.B.I. dan Moreki, J.C. (2012). Nutrient composition and feeding value of sorgum for livestock and poultry: a review. Journal of Animal Science Advances 2: $510-524$.

Fadlallah, O.E., El Tinay, A.H dan Babiker, E.E. (2010). Biochemical characteristics of sorgum flour fermented and/or supplemented with chickpea flour. International Journal of Biological and Life Sciences 6: $21-23$.

Fathurrohman, F. (2012). Kajian Karakteristik Kimia dan Fisik Tepung Sorgum (Sorgum bicolor L.) Termodifikasi Varietas UPCA dengan Variasi Lama Fermentasi dan Konsentrasi Starter Bakteri Asam Laktat Lactobacillus acidophilus. Skripsi Universitas Sebelas Maret. Surakarta.

Kurniadi, M., Andriani, M., Faturohman, F., Damayanti, E. (2013). Karakteristik Fisiokimia Tepung Biji Sorgum (Sorghum bicolor L.) Terfermentasi Bakteri Asam Laktat Lactobacilllus acidophilus. AGRITECH, Vol. 33, No. 3,

Murtini, E. S., Radite, A. G., Sutrisno, A. (2011). Characteristics of chemical content and digestibility of brown sorgum tempeh. (Karakteristik kandungan kimia dan daya cerna tempe sorgum coklat (Sorgum bicolor). Teknologi dan Industri Pangan. 22(2); 149-154

Murtini, E. S., Atmaja M I P,Sutrisno, A. (2016). Pengaruh Metode Fermentasi Padat dan Substrat dan Substrat Terendampada Biji Sorghum terhadap Kualitas Tepung ,Teknologi dan Industri Pangan. 27(1); 59-67

Pranoto, Y., Anggrahini, S., \& Efendi, Z. (2013). Effect of natural and Lactobacillus plantarum fermentation on in - vitro protein and starch digestibilities 
of sorgum flour. Food Bioscience, 1-7. doi:10.1016/j.fbio.2013.04.001

Ruchjaniningsih. (2009). Rejuvenasi dan karakterisasi morfologi 225 aksesi sorgum, (1960), 978-979

Setiarto, R.H.B., Widhyastuti, N., Saskiawan, I. (2016). Pengaruh Fermentasi Fungi, Bakteri Asam Laktat dan Khamir terhadap Kualitas Nutrisi Tepung Sorgum. AGRITECH, Vol. 36, No. 4, November 2016, Hal. 440-449

Singh J, Dartois A,Kaur L 2010 Starch digestibility in food Matrix a review, Food Sience Technology, 21 ,168-180

Xu, X., Waters, D., Blanchard, C., Tan, S.H., 2020, A study on Australian sorghum grain fermentation performance and the changes in Zaopei major composition during solidstate fermentation, Journal of Cereal Science, 